\title{
CORRESPONDENCE.
}

\section{MR. FINLAISON'S REPORT AND THE ENGLISH LIFE TABLE.}

\section{To the Eatitor of the Assuranee Magazine.}

Sir,-The letter of Mr. Porter, in your last number, contains so many questionable assertions, and does such injustice to one of the most valuable tables of mortality we possess, as to require some further notice.

The information contained in the tables of Mr. Finlaison's Report is of great interest and valne; the accompanying remarks, embracing a variety of different subjects, as might be expected, afford room for considerable difference of opinion. But most of your readers will probably agree in thinking, that the greater part of the eleven pages devoted to criticising the English Life Table would have been advantageously omitted. That Mr. Finlaison should look with some disfavour upon actuarial investigations proceeding from another Government department than his own, is not, perhaps, very surprising; but that Mr. Porter, passing over so much that is valuable in the Report, should have chosen this particnlar passage for comment, is in every way unfortunate. What have the records of the National Debt Office to do with the census returus of 1851 ? The portion of the latter, referring to the ages of the population, was published in 1854 , and the facts were generally commented upon at the time. Why, then, has Mr. Porter, with his strong opinion of their worthlessness, allowed them to pass for seven years unnoticed?

Mr. Porter has made a general summary of his remarks under six heads, upon each of which I will say a few words.

" 1 . The inordinate extent to which the ages of females between the ages of-say, 20 and 40 -are understated in the census."

Could anyone, whose only information on the subject was derived from Mr. Porter's letter, suppose that the anthors of the Report of the Census for 1851 expressed a decided opinion of the general accuracy of the returns of the ages both of males and females, and that the passage quoted (or rather misqnoted) in Mr. Finlaison's Report, on which Mr. Porter lays so much stress, was actually written in support of this opinion? Such is, however, the fact; but, by the omission of eight words, the meaning of the passage is entirely perverted, and the Registrar-General and his colleagues are made to express an opinion diametrically opposite to the one they really entertain. On reference to the Report of the Census for 1851, part 2, vol. i., pages 23 and 24, it is stated, that-" The mean age of the females, as they are retarned in England, exceeds the mean age of the males by ten months; so that the tendency in women to understate their ages has only operated on comparatively small numbers; and there is no donbt of their general truthfulness." Some further reasons in support of this view are then given; at the same time, we are informed that at certain ages there are some evident misstatements, which, however, admit of being corrected. Then follows the passage quoted in your Magazine, page 278, which is correctly given for the first portion, but which in the original proeeeds as follows:"The extensive immigration of the Irish into Great Britain during the 10 years, 1841-51, has exercised some disturbing influence on the proportions; but, upon comparing the above numbers with those for males at the corre- 
sponding ages, the conclusion appears to be inevitable that some 35,000 ladies, more or less, who have entered themselves in the second age, 20-40, really belong to the third age, 40-60; to which the body of delinquents are transferred in Table 7. Millions of women have returned their ages correctly; thousands have allowed themselves to be called 20 , or some age near it, \&c." The words in italics are omitted in the quotation; and the meaning intended to be conveyed is, in consequence, entirely misrepresented. The plain signification of the passage is - that there was no donbt of the general truthfulness of the returns of the ages; that there were some inaccuracies at particular periods of life, but only in the proportion of thousands to millions; that these inaccuracies admitted of correction, and had been corrected accordingly.

Mr. Porter, having thus proponnded a statement which is altogether untrue (inadvertently, of course, but which a very little research would have prevented), proceeds, in language which $I$ must be allowed to characterise as neither courteous, nor manly, nor jnst, to declaim against the ladies for their supposed want of veracity. But the indignation which began to be aroused at this charge soon passed into a smile at the remedy suggested, viz., that ladies should add to their other accomplishments a knowledge of Horace! and that their especial attention should be directed to one of the odes, which, in my time at least, young gentlemen in the course of their studies were usually recommended to omit.

“ 2 . The over-estimate of age in very advanced life, both in the census and in the registers of death."

Mr. Porter refers particularly to ages above 100, and remarks that it is a curions fact, that members of the Peerage never attain to fabulous age. Here, again, a little investigation into the real facts quite alters his view of the case. In the census of 1851 , there were found 319 centenarians ont of a population of $21,185,010$, or only 1 in 66,411 . I see no improbability in this, especially as in some researches on the families of the Peerage, recently made by $\mathrm{Mr}$. Day and myself, we found 2 centenarians out of 7,473 cases, or 1 in 3,736 .

"3. The loose system adopted in ascertaining the ages at death of all classes of people, at all ages."

This is a matter within the experience of everyone; the description given by Mr. Porter is borrowed from his own imagination. The simple fact is, that medical men exereise no judgment whatever upon the ages at death; the cause of death is another matter, but the age inserted in the certificate is derived from the information of relations and friends. As with the ages of the living, there are probably several errors of one or two years in both directions, but there is no reason to donbt the substantial accuracy of the retarns. And in applying the results to the constrnction of life tables, it must be remembered that the changes made in the process of graduation are so extensive, that the individnal errors in the returns are comparatively unimportant and probably would not affect any pecuniary results.

"4. The direct pecuniary loss sustained by females in the purchase from the Government, or from such Annuity Companies as adopt special scales for female lives, on the present assumption of the vitality of females being so much in excess of that of males."

This is quite new information. Mr. Hendriks, some years ago, contributed to the Statistical Journal an elaborate paper on the "Loss sustained 
by Government in granting Annuities." As regards the mortality, the Government tables since 1829 have been dednced from their own experience; and the superior vitality of females, which Mr. Porter calls an assumption, is, at all events as regards annuitants, an incontestable fact, proved by many years' experience. The established Assurance Companies, with hardly an exception, have discontinued to grant annuities, because they have found the business unprofitable; and as the majority of annuitants are females, there can be no doubt that the "direct pecuniary loss" has been on the contrary side to what Mr. Porter alleges.

"5. The advantage the female sex might derive, were Life Assurance Companies to adopt special rates of premiam for female lives."

Surely Mr. Porter cannot be ignorant that this experiment has been more than once tried and abandoned! For nearly a quarter of a century the Eagle Office adopted special preminms for female lives. A careful investigation into the results of the experience of this Office was made by Mr. Jellicoe, and published in this Magazine (vol. iv., page 199). In the course of his remarks, Mr. Jellicoe observes- "One inference is, at all events, fully supported by these data, viz., that the insurance of female life at less rates than that of male is scarcely justifiable."

"6. The general discredit thrown upon the English Life Table, both for males and females, and the necessity that exists for Life Assurance and Annuity Companies to abstain from using it, in consequence of the incorrect returns, which, both as regards the numbers living and the numbers dying at each age, have been, no doubt, habitually made to the census-enumerators and the Distriet Registrars of Deaths."

With a passing remark, that all Mr. Porter's objections wonld apply with much greater force to the Carlisle Table, against which he says nothing, I will briefly give my reasons for taking exception to this sweeping censure: The English Life Table is based, not upon the census of 1851, but upon that of 1841 , where the return of ages was made in quinquennial intervals only; and the first process was to obtain the annual mortality in quinquennial periods of age. Even when treated in this manner (vide RegistrarGeneral's 5th Annual Report, page 347), it was fonnd that, as with other similar observations, the series for both sexes exhibited great irregularities. Corrections were made by means of Mr. Gompertz's hypothesis, that the rate of mortality may be represented by the expression $a q^{z}$; and Dr. Farr accordingly reduced the annual mortality above the age of 15 to two geometrical series with a different common ratio, one for the interval from 15-55, and the other from 55-95. The result is, a table of mortality very convenient for practical nse, upon the accuracy of which we rely-both because we believe the ages both of the living and dead to have been given with sufficient accuracy for pecuniary purposes (which is quite compatible with several individual errors), and also because it is consistent with the results of other trustworthy observations. To apply a most stringent testlet ns compare the English Life Table with Mr. Finlaison's tables, taking the two identical examples quoted by him to establish the inaccuracy of the former. (1) Ont of 2,000 persons living at the age of 55 , there survive to 75 by the English Life Table 778, and by the Government Table 901, persons. Is not this precisely what was to have been expected? The tontine nominees, upon whom the bulk of Mr. Finlaison's observations in early life are made, are recruited in old age by a very seleet body of lives of a different class - the annuitants, properly so called. Can, then, anyone be 
surprised at the Government tables indicating a more favourable mortality between the ages of 55 and 75 , than that of the general population? Had a contrary result been arrived at, would there not have been much more reason to doubt the accuracy of the English Life Table? (2) At the age of 27, taking interest at 4 per cent., the annual premiam to assure

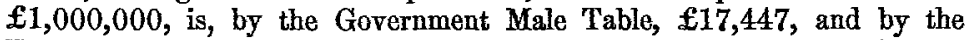

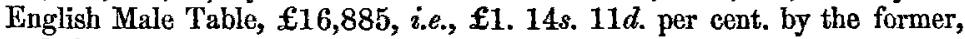
and $£ 1$. $13 s .9 d$. per cent. by the latter, the difference being one shilling and two pence per cent. To my comprehension, this proves the accuracy of the English Life Table; and to confirm my impression, I referred to the prospectus of the Office from which Mr. Porter writes, and, comparing the tables with those of the Royal Exchange Office (the selection being made almost at random), made the discovery that at this identical age of 27 , the rates of premium of these two Offices differed as much as two shillings and eleven pence per cent.

But, Mr. Porter remarks, the last example is derived from male lives only, and an Assurance Company conld only employ a table based on a combination of both sexes. Now, as we know by experience that the proportion of the sexes amongst assured lives is about 9 males to 1 female, I think that it would be more judicious for an Assurance Company to employ a table of mortality deduced from male lives only. Otherwise, I do not think sufficient reason has been shown for distrusting the English Female Life Table; and it is curious, that neither Mr. Finlaison nor Mr. Porter should have discovered that the blow they aim at it recoils on themselves. If, as they would have us believe, between the ages of 20 and 40 the numbers living are enormously overstated, while at the same time the ages at death are more accurately given, it follows that the mortality during that period must be much greater than the table indicates. Yet, with strange inconsistency, one of their objections to the table is, that it represents the mortality of females at the yonnger adult ages to be so great as to be contrary to nature.

Having myself, for some years, been in the practice of using the Male English Life Table for Assurance calculations, I should have been glad to have given my reasons for thinking that, in the present state of our knowledge, this table is better adapted for the purpose than the others in common ase. But having already trespassed too much on your space, I will conclude by commending the English Life Table to Mr. Porter's more careful study, requesting him, in the words of the author whom he wishes ladies to read for their moral improvement-

"Si quid novisti rectius istis

Candidus imperti, si non, bis utere meenm."

$$
\text { I am, Sir, }
$$

Your obedient servant,

Equity and Law Life Offec,

ARTHUR H. BAILEY. 11 th $M a y, 1861$. 